\title{
$\frac{173}{1-2} 1-959+50$
}

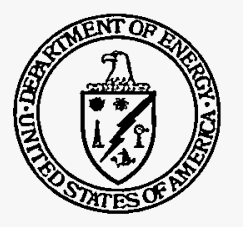

\section{PCB Storage Requirements}

BACKGROUND:

STATUTE:

REGULATION:

REFERENCES:
Polychlorinated biphenyls (PCBs) are a class of organic chemicals that had become widely used in industrial applications due to their practical physical and chemical properties. Historical uses of PCBs include dielectric fluids (used in utility transformers, capacitors, etc.), hydraulic fluids, and other applications requiring stable, fire-retardant materials. Due to findings that PCBs may cause adverse health effects and due to their persistence and accumulation in the environment, the Toxic Substances Control Act (TSCA), enacted on October 11, 1976, banned the manufacture of PCBs after 1978 [Section 6(e)]. The first PCB regulations, promulgated at 40 CFR Part 761 , were finalized on February 17, 1978. These PCB regulations include requirements specifying disposal methods and marking (labeling) procedures, and controlling PCB use. To assist the Department of Energy (DOE) in its efforts to comply with the TSCA statute and implementing regulations, the Office of Environmental Guidance has prepared the document "Guidance on the Management of Polychlorinated Biphenyls (PCBs)." That document explains the requirements specified in the statute and regulations for managing PCBs, including PCB use, storage, transport, and disposal.

The requirements specified at 40 CFR Part 761.65 require most PCB wastes to be stored in a facility that meets the specifications of that section. Additionally, the regulations include rules concerning time limits for PCBs and PCB Items in storage, rules concerning leaking electrical equipment, and rules concerning types of containers used to store PCBs and PCB Items. This Information Brief supplements the PCB guidance document by responding to common questions concerning storage requirements for $P C B s$. It is one of a series of Information Briefs pertinent to PCB management issues.

Toxic Substances Control Act of 1976 (TSCA)

40 CFR Part 761

1. "Guidance on the Management of Polychlorinated Biphenyls (PCBs)," Environmental Guidance Manual, DOE Office of Environmental Guidance, RCRA/CERCLA Division (EH-231), DOE/EH-0350, June 1993.

2. "РCB Manufacturing, Processing, Distribution in Commerce, and Use Bans," Final Rule, Environmental Protection Agency, 44 FR 31514, May 31, 1979.

3. "PCB Use in Electrical Equipment," Final Rule, Environmental Protection Agency, 47 FR 37342 , August 25, 1982.

4. "TSCA Statement of Policy for Compliance and Enforcement of PCB Storage for Disposal Regulations," Final Rule, Environmental Protection Agency, 48 FR 52402, November 17, 1983.

5. "PCB Manifesting, Tracking, and Disposal Requirements," EH-231 TSCA Information Brief, EH-231001/1190, DOE Office of Environmental Guidance, RCRAJCERCLA Division, November 1990.

6. "PCB Spill Response and Notification Requirements," EH-231 TSCA Information Brief, EH-231-059/1294, DOE Office of Environmental Guidance, RCRA/CERCLA Division, December 1994.

\section{What is considered a "PCB storage facility"?}

For a facility to be a "PCB storage facility" under the regulations at $40 \mathrm{CFR} 761.65$ (b), it must meet a set of specific criteria. These criteria include (1) an adequate roof and walls, (2) a floor that minimizes penetration of PCBs, and (3) a 6-inch-high curb that provides a containment volume equal to at least twice the internal volume of the largest PCB Item (i.e., a manufactured item containing or contaminated with $\mathrm{PCBs}$ ) or $25 \%$ of the total internal volume of all PCB Items stored in the facility. The facility may not have any openings, expansion joints, or drains that would permit liquids to flow from the curbed area. Additionally, the facility must be located at or above the 100-year flood elevation.

\section{What types of PCBs and PCB ltems must be stored in a PCB storage facility?}

Most PCBs and PCB Items with a concentration of $\geq$ $50 \mathrm{ppm}$ and that have been declared to be a waste must be stored in a PCB storage facility prior to disposal. PCB wastes containing $<50 \mathrm{ppm}$ PCB as a result of dilution must also be stored in a PCB storage facility. However, 
there are some PCB Items that are excluded from these requirements and are discussed later in this Information Brief. The other category of PCBs that must be stored in a PCB storage facility includes PCB dielectric fluid with a $P C B$ concentration of $\geq 50 \mathrm{ppm}$ that is in storage for use or reuse (i.e., dielectric fluid used to service PCB transformers, electromagnets, switches, or voltage regulators).

Large PCB equipment such as structurally undamaged PCB Large High-voltage Capacitors (i.e., capacitors containing 3 pounds or more of dielectric fluid and operating at or above 2,000 volts) and undrained PCBcontaminated electrical equipment (e.g., transformers with a PCB concentration of $<500 \mathrm{ppm}$ ) that are in storage for disposal may be placed on pallets adjacent to the storage facility as an alternative to storage inside a PCB storage facility. If equipment is stored on pallets adjacent to a storage facility, that facility must have immediately available unfilled storage capacity equal to at least $10 \%$ of the volume of the equipment stored outside the facility.

\section{What is considered a temporary storage facility under the regulations and how does that differ from a PCB storage facility?}

A temporary storage facility is one that is not required to meet the PCB storage facility specifications, provided that PCB waste is stored there for 30 days or less. For example, a temporary storage facility is not required to meet the 6-inch curbing requirements or the requirement that it be located above the 100-year flood elevation.

Most PCBs and PCB Items may be stored in temporary storage facilities for up to 30 days from the date of their removal from service. This includes PCB Items, PCB Containers holding non-liquid PCB wastes (i.e., soil, debris, rags, etc.), and PCB Containers holding liquid PCBs with a concentration $<500$ ppm PCB. Liquids with a PCB concentration of $\geq 500$ ppm may not be stored in a temporary storage facility. Furthermore, containers of $\mathrm{PCB}$ liquids in a temporary storage facility must be marked with a notation stating that the PCB concentration does not exceed $500 \mathrm{ppm}$.

\section{Are any types of PCBs or PCB Items exempt from the TSCA storage regulations?}

Yes. The TSCA regulations at $40 \mathrm{CFR}$ Part 761 do not regulate storage of the following materials:
PCBs and PCB Items with a PCB concentration $<50 \mathrm{ppm}$, as long as the $\mathrm{PCB}$ concentration was not the result of dilution,

PCB Small Capacitors (i.e., capacitors containing less than three pounds of PCB dielectric fluid) and other manufactured items that contain PCB Small Capacitors, such as fluorescent light ballasts,

hydraulic machines, provided that they have been drained of hydraulic fluid (and flushed if the PCB concentration in the hydraulic fluid was $\geq 1,000$ $\mathrm{ppm}$ ), and

drained electrical equipment (such as transformers) with a PCB concentration of $<500 \mathrm{ppm}$.

Additionally, PCB Items at any PCB concentration may be stored indefinitely for use or reuse as long as a plausible future use has been identified for the equipment. Usable PCB Items stored for use or reuse do not have to be stored in a facility meeting the specifications of 40 CFR 761.65(b) (i.e., a "PCB storage facility").

\section{Is there a time limit on how long PCBs and PCB Items may be stored in a PCB storage facility?}

Yes. Thetotal time of storage before disposal may not exceed 1 year. Waste PCBs, PCB Items, and dielectric fluid subject to the disposal regulations may be stored for up to 9 months before they must be shipped to a TSCAapproved disposal facility. The disposal facility is then allowed up to 3 months to dispose of the waste. For containers of liquid PCB waste, the 1-year time limit for storage begins on the date that the first batch of PCB waste is added to the container. The 1-year time limit for the storage of all other PCB wastes begins when the materials are first declared $a$ waste or are no longer fit for use.

\section{What are the storage requirements for leaking PCB electrical equipment?}

Most PCB Items must be drained prior to disposal. To prevent leaks while in storage, it may be worthwhile to drain waste PCB equipment (where practicable) prior to storage.

If leaks occur while a PCB Item is in storage, the leaking PCB Item must be transferred immediately to a properly marked, non-leaking container. The spilled or 


\section{DISCLAIMER}

This report was prepared as an account of work sponsored by an agency of the United States Government. Neither the United States Government nor any agency thereof, nor any of their employees, make any warranty, express or implied, or assumes any legal liability or responsibility for the accuracy, completeness, or usefulness of any information, apparatus, product, or process disclosed, or represents that its use would not infringe privately owned rights. Reference herein to any specific commercial product, process, or service by trade name, trademark, manufacturer, or otherwise does not necessarily constitute or imply its endorsement, recommendation, or favoring by the United States Government or any agency thereof. The views and opinions of authors expressed herein do not necessarily state or reflect those of the United States Government or any agency thereof. 


\section{DISCLAIMER}

Portions of this document may be illegible in electronic image products. Images are produced from the best available original document. 
leaked material must then be cleaned up immediately according to the TSCA PCB Spill Cleanup Policy at 40 CFR 761 Subpart G (see Reference \#6). All PCBcontaminated materials must be disposed of as PCB waste with a PCB concentration equal to the PCB concentration of the leaking item.

\section{How often should PCBs and PCB ltems in storage be inspected for leaks?}

PCBs and PCB Items stored in a PCB storage facility or stored in accordance with the temporary storage provisions must be inspected for leaks at least once every 30 days. PCBs and PCB Items stored on pallets adjacent to a PCB storage facility must be checked for leaks weekly.

\section{What types of containers are required to store various PCBs and PCB Items?}

The TSCA regulations require the use of containers that meet specifications established by the U.S. Department of Transportation (DOT) at 49 CFR Part 178; however, alternative storage containers may be used if a container larger than DOT-specified containers is needed. On October 1, 1991, DOT revised the Hazardous Materials Regulations [49 CFR Parts 171-180]. The revised requirements [DOT HM181] phase out detailed design specifications for containers and receptacles and institute new standards based on performance criteria. Facilities may not use containers manufactured under the "old" specification after October 1, 1996.

If an alternative container is used, it must provide at least as much protection against leaking and environmental exposure as the DOT-specification containers. EPA must grant an approval of the alternative container. Also, if an alternative storage container is used to store liquid PCBs, it must be designed, constructed, and operated in compliance with the Occupational Safety and Health Administration (OSHA) standards for flammable and combustible liquids. It is not necessary for intact, non-leaking PCB equipment to be stored in a storage container.
What is a Spill Prevention, Control, and Countermeasure (SPCC) Plan and when must it be prepared?

The SPCCPlan is developed by the facility to provide for the following: appropriate containment and/or diversionary structures to collect spills and prevent $\mathrm{PCBs}$ from reaching navigable water, appropriate storage tank and transfer facility design, periodic inspection for leaks, and corrective action to repair any leaks or faulty equipment.

SPCC Plans must be prepared and implemented for liquid PCBs that are stored in alternative containers. SPCC Plans are also needed for temporary storage areas in which containers of liquid PCBs at concentrations of between 50 and $500 \mathrm{ppm}$ are stored. Managers should be aware that the TSCA requirements for an SPCC Plan can be satisfied by including PCBs in SPCC Plans developed by the facility under other authorities (e.g., the Clean Water Act).

Is the movable equipment that is used in handling PCBs and PCB ltems in storage areas subject to any restrictions?

Movable equipment (e.g., forklifts, storage pallets, etc.) used to handle PCBs and PCB Items in a PCB storage facility may not be removed from the storage area unless the equipment has been decontaminated in accordance with the provisions at 40 CFR 761.79.

Facilities may wish to designate equipment for the sole purpose of handling PCBs and PCB Items.

Questions of policy or questions requiring policy decisions will not be addressed in EH-231 Information Briefs unless that policy has already been established through appropriate documentation. Please refer any questions concerning the subject material covered in this Information Brief to Carolyn Thompson Waider, RCRA/CERCLA Division, EH-231, (202) 586-8248. 
Post Office, if unable to deliver please return to:

Gabrielle Santore

Environmental Compliance Group

Building 800 TPK, MS-6482

Oak Ridge National Laboratory

Oak Ridge, TN 37831-6482

ADDRESS CORRECTION REQUESTED 